\title{
Domestic dogs in rural area of fragmented Atlantic Forest: potential threats to wild animals
}

\author{
Cães domésticos em uma área rural fragmentada da Mata Atlântica: \\ ameaça potencial para os animais selvagens
}

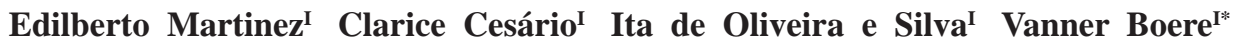

\begin{abstract}
Domestic dogs' skills such as hunting and herding shifted as man migrated from rural areas to developing urban centers and led to a change in human-dog relationship and in the purpose of these animals in the properties. The countryside of Viçosa is characterized by small coffee farms surrounded by borders with fragments from the Brazilian Atlantic Forest. The close proximity of these environments favors the encounter between domestic and wild animals which may lead to dog attacks to wild animals and, consequently, disease transmission. The aim of this study was to understand the role of dogs in the rural environment and assess the possible risks they offer to native fauna. The data were obtained from structured questionnaires answered by dogs' owners from rural Viçosa. Results regarding the socioeconomic status of the owners revealed that the majority belonged to either the middle class or low educational level categories. In addition, it was observed that there is a preference for male dogs due to its guard activity and that most dogs live unconstrained. Even though most dogs are provided with good food management, 58\% of them prey on wildlife. However, more than half of the dogs do not consume their prey which can be explained by the inherited ability of artificial selection but $36.5 \%$ of them have scavenger diet. Most of the dogs were immunized against rabies, whereas, only 28.8\% were immunized against infectious diseases such as leptospirosis, distemper and parvovirus. In conclusion, the management of dogs by rural owners, mainly unrestrained living, and allied to inadequate vaccination coverage suggest that dogs are predators of Viçosa's rural wildlife and potential disseminators of disease.
\end{abstract}

Key words: Atlantic forest, Canis lupus familiaris, domestic dog, rural.

\section{RESUMO}

As habilidades dos cães domésticos como caçadores e pastores modificaram com a mudança do homem das áreas rurais para os centros urbanos em desenvolvimento, levando para uma mudança nas relações humanos-cães e o propósito

\begin{abstract}
desses animais nas propriedades. O município de Viçosa é caracterizado por pequenas fazendas com cafeicultura, cercadas nas bordas por fragmentos de Mata Atlântica. A proximidade desses ambientes favorece o encontro entre animais domésticos e selvagens, que pode resultar em ataques de cães sobre a fauna e, consequentemente, levar à transmissão de doenças. O objetivo do presente estudo foi compreender o papel de cães no ambiente rural e avaliar os possíveis riscos que eles oferecem para a fauna nativa. Os dados foram obtidos aplicando-se questionários estruturados respondidos pelos proprietários de cães rurais de Viçosa. Os resultados a respeito do status socioeconômico dos proprietários revelaram que a maioria pertence à classe média e baixo nível educacional formal. Há uma preferência por cães machos, devido à atividade de guarda e a maior parte vive sem contenção. Apesar de que a maioria tenha um bom manejo alimentar, 58\% dos cães predam animais selvagens. Entretanto, mais da metade dos cães não consome suas presas. A maioria dos cães foi imunizada contra a raiva, mas somente $28,8 \%$ foram vacinados contra doenças infecciosas como leptospirose, cinomose e parvovirose. Concluise que o manejo dos proprietários, principalmente a falta de contenção, aliada à cobertura imunoprofilática, sugere que os cães são potenciais predadores e disseminadores de doenças sobre a fauna selvagem de Viçosa.
\end{abstract}

Palavras-chave: Mata Atlântica, Canis lupus familiaris, cão doméstico, rural.

\section{INTRODUCTION}

In the recent decades, most of the Brazilian rural population migrated to urban areas (HOGAN, 2010). As cities grew, the countryside parts of industrialized and urbanized countries improved, and there were economic and social relations changes established in rural areas, where the replacement of human labor and the technology to increase

IPrograma de Pós-graduação em Biologia Animal, Departamento de Biologia Animal, Universidade Federal de Viçosa, Viçosa, MG, Brasil. E-mail: vannerboere@uol.com.br.*Autor para correspondência. 
production contributed to the rural exodus (HOGAN, 2010). The new socioeconomic patterns are evidenced in the relationship between humans and dogs from rural areas.

However, few studies evaluated these changes (BUTLER \& BINGHAM, 2000; KITALA et al., 2001; ACOSTA-JAMETT et al., 2010). In the rural region of Viçosa, Minas Gerais state, where there is a predominance of coffee production (Coffea arabica) (PEREIRA et al., 2001), the role of dogs is not well clarified. This functional new role can be a consequence of new laws that regulate the activity of deforestation and exploitation of natural resources, together with the highly restrictive rules imposed on hunting in recent decades (VERDADE \& CAMPOS, 2004). Hunting breed dogs, for example, may be restricted to a secondary role being supplanted by breeds raised to guard the property.

The rural zone has many wild animal species, including vulnerable or threatened animals (RIBON et al., 2003; PRADO et al., 2008). The proximity of humans to protected areas has enabled the entrance of dogs that can chase, injure and kill wildlife animals (MARKS \& DUNCAN, 2009). Furthermore, this dog invasion increases the risk of transmission of infectious diseases to the local fauna (DASZAK et al., 2000). There are few studies of the impact of dogs raised in rural areas, on the natural resources found in the Atlantic Forest, which is a biome severely threatened by intensive deforestation (PEREIRA, 2005). Therefore, the lack of systematic care and infrastructure have enabled hunters or gatherers to enter protected areas, often accompanied by dogs, representing a serious threat to biodiversity in these lightly protected areas (ALVES et al., 2009).

Dogs are an important terrestrial rabies reservoir, therefore widespread vaccination is carried on every year by public health officers in Brazil, with no charges to the owners. Despite the systematic vaccination campaign, there is some rabies focus in rural areas, mainly in cattle and wild animals (CARNIELI et al., 2009). Due to vaccine failures, dogs are suspected of transmitting rabies in some countryside's around the world (CARNIELI et al., 2009). In recent years few scientific studies were conducted in rural areas of Brazil regarding dog vaccination against distemper, parvovirusis and leptospirosis (WHITEMAN et al., 2007). The contact or proximity of wild animals with unvaccinated dogs suggests a high risk of infectious diseases transmission.

Owing to socioeconomic context and ecological changes in rural areas, the roles of dogs can change as well. Strict role of work dog like shepherding, hunting or guarding on rural areas could be changing to a companion animal role or an unspecific function. Anyway, dogs can attack and transmit infectious diseases to wild animals, mainly if rural owners are neglect on dog care. In order to understand if dogs can threat wild fauna, we carried out an investigation through interviews with landowners in a municipality located within the Atlantic forest.

\section{METHODS}

We applied structured questionnaires to dog owners living in the rural zone of Viçosa, ( $\left.20^{\circ} 45^{\prime} \mathrm{S}, 42^{\circ} 52^{\prime} \mathrm{W}\right)$, Minas Gerais state, Brazil. This region has $299.418 \mathrm{~km}^{2}$. The most rural zone of Viçosa is composed by little farms (IBGE, 2010) where the main economic activity is coffee cultivation, and in minor scale, dairy and poultry production (PEREIRA, 2005). Coffee cultivation and pastures to dairy cattle occupy 68 and $11.9 \%$ of the area, respectively (IBGE, 2010). Farms are separated by hedges, barbed and barbless fencing wires, allowing dogs to free locomotion between different neighborhood places. Local vegetation is seasonal montane semideciduous forest, distributed in fragmented secondary forests on mountain tops (PEREIRA et al., 2001). There is estimated that the preserved forests are 20.1\% of the total rural area. The activity of leisure, sport or economic exploration is legally forbidden in the preserved private forests. There were 4.915 persons living in the rural zone of Viçosa at the year of 2010 (IBGE, 2010).

For the survey, we traveled by car on four paved or dusty roads, directed to four points on the compass (N, E, S and W), in different days between August to November, 2011. The respondents were chosen by chance, each 0.5 to $1.5 \mathrm{~km}$, after the urban border from the city was crossed. Farmers were approached and given an explanation of the study's objectives. Upon verbal agreement to participate in the study the participants were given a written informed consent to sign.

We asked three different sets of questions for each respondent, the first one aimed to gather information about the economic and cultural status of the dog's owner (adapted from FERRANTE et al., 1976). Five general inquiries were included: kind of home, formal education level, profession, number of cars and number of persons living in the farm.

The second set of questions, inquired about the relationship between the owner and the 
animal, mainly focusing on health care, management and functional aspects of the dog. The immune status of dogs was given special consideration and included vaccination against rabies, distemper and parvoviruses.

The third set of questions concerned dog's behavior, such as predation, locomotion, feeding, playfulness, and reproduction. Only dogs over one year of age were included in this study. Dogs under one-year-old were excluded since their body and behavior are not fully developed as to represent a serious threat to injury wild animals (BUTLER \& TOIT, 2002). Completion of data collection included breed and clinical aspects of the dogs as well as photographs from each one. Data was analyzed by descriptive statistics.

\section{RESULTS}

We contacted 80 rural properties, however, four respondents declined to participate in the study. Overall responses were obtained for 209 dogs and each property had $2.6 \pm 1.5$ dogs. The proportions of the gender data obtained from the respondents were $56.25 \%$ of men and $43.75 \%$ of women. Most of the respondents belonged to the middle class (66\%), while $32.5 \%$ belonged to the lower class and $1.5 \%$ to the upper class. Regarding the educational level, $16.2 \%$ of respondents had no formal schooling, $48.6 \%$ attended elementary school, and $27.6 \%$ had up to high school and $7.5 \%$ attended a higher-education school.

Most of the dogs are mongrels (78\%). The remaining $22.3 \%$ of purebred dogs had a profile of guard or hunting dogs except for those that belonged to Miniature Pinscher breed. Rottweiler, Pit Bull and Brazilian Mastiff, together accounted for 39\% of purebred dogs. There is lack of a specific function for $18.3 \%$ of these dogs. A small portion of rural dogs (5.1\%) are still being used for hunting. Regarding the gender, there are more male dogs (63.3\%) than females (36.7\%). Also, results in regard to feeding practices showed that the majority of owners provide a commercial feed to their animals (47.1\%) or mixes it with leftovers (29.3\%). A minority of owners (23.6\%) provides only leftovers to dogs. Anyway in $84.4 \%$ of cases the animals were fed more than once a day.

In regard to lifestyle, $69.8 \%$ of the dogs live loose, with access to internal and external areas of properties. It was reported that the $13.7 \%$ of the dogs are chained or kept in kennels. Some owners were found to keep dogs $(16.5 \%)$ in mixed systems of containment and release daily. Furthermore, respondents reported that half the dogs (51\%) left the property at night regularly and $44.3 \%$ during the day. Almost half of respondents (47.9\%) walk with the dogs in conservation areas for recreational, livestock management and hunting purposes. The other 50.5\% of the dogs roam freely in these areas without human guidance. In this study, $28.9 \%$ of the interviewees reported that dogs showed up injured after leaving the property, mostly in the facial area, being usual (67.5\%) the presence of hedgehog (Coendou prehensilis) spines, with recurrence of this type of injury.

Owners answered that $58 \%$ of the dogs prey upon wildlife. $56.8 \%$ of the dogs were reported to have attacked animals of small and medium size. In addition, large mammals have also been attacked by dogs (20.3\%). Dogs (33.3\%) attack birds and nests with or without nestlings or eggs too. The interviewees reported that upon successful hunt $29.5 \%$ of the dogs simply abandon their prey, while $70.5 \%$ have some kind of interaction with it. Amongst the interactions with the prey, owners observed dogs to play (78.5\%), to ingest (45.2\%) and to bury (21.4\%). It is noticeable that the dog-prey interactions are not mutually exclusive, and above of two interactions on the same prey was possible. In addition, the data obtained in this study showed that $36.5 \%$ of the dogs eat rotting carcasses of wild animals while $39.6 \%$ roll over them.

The majority of dogs (83.6\%) received some type of anti-parasitic treatment and that $97.1 \%$ of the owners vaccinated their dogs against rabies last year. In regard to other infectious diseases (distemper virus or CVD, parvovirus, coronavirus and leptospirosis), only $28.8 \%$ of the dogs are vaccinated regularly, in contrast to the $71.2 \%$ that had never been vaccinated against any of these infectious agents.

\section{DISCUSSION}

The results of the present survey suggest owners living in the rural area of Viçosa fail to manage their dogs. Rural dogs in Viçosa are fed regular pet chow and vaccinated against rabies. However, the majority of dog's owners fail to control their dog's behaviors and completely vaccinate against infectious diseases. Therefore, dogs in the rural areas from Viçosa are a potential risk to wildlife conservation.

Over the years domestic dogs were selected to serve several functions in rural areas such as herding, guarding of properties and hunting (SVARTBERG, 2006). In the rural area of Viçosa dogs are used to guard and to a lesser extent for other activities. Despite hunting being a prohibited activity 
to citizen and considered crime by the Brazilian environmental legislation, some trained dogs are used to pursue or sometimes to kill the local fauna for unknown purposes (ALVES et al., 2009).

The absence of a specific function, as observed in $18.3 \%$ of these dogs, suggests a shift value of the dog as a functional animal. The presence of some dogs in rural areas without function neither affection is suggestive there is a cultural remnant of a time when there were functions to be fulfilled by dogs. In this case it seems dogs are only tolerated around homes and vicinity. Mongrel dogs are more abundant than purebred dogs. Owners are according to the popular concept that mongrels are more resistant to diseases and the belief that they live longer than purebreds.

There are more male dogs than female, a phenomenon was also observed in studies with rural dogs from Mexicali (Mexico), Machakos (Kenya), Nakhon Si Thammarat (Thailand), Navajo reserve (USA) and from five agro-ecological regions of Zimbabwe, Central region of Philippines and Coquimbo (Chile) (DANIELS \& BEKOFF, 1989; BUTLER \& BINGHAM, 2000; KITALA et al., 2001; ACOSTA-JAMETT et al., 2010). Male dogs exposed to men react with fewer interactive social behaviors than when exposed to women (WELLS \& HEPPER, 1999). Considering that most owners raise dogs to guard and most theft crimes are attributed to men (STEFFENSMEIER \& ALLAN, 1996), the preference for male dogs compared to females may be explained by the subtle owners' perception of male dogs' aggressiveness towards men. Another reason is the lack of control of females' estrous cycle, despite enshrined techniques such as surgery and pharmacological control. The cause of this of lack control is not clear, but some owners have reported the high costs and the need for skilled labor to sterilize the animals. Moreover, the free motion of dogs between properties is an inconvenience during the rut because it attracts males into the property (WIRANT \& MCGUIRE, 2004) which, in turn, probably interferes with choosing the sex of the animal. In addition, unplanned pregnancy results in unwanted puppies and may create more trouble to the owner.

Dogs in the rural area of Viçosa have a greater nutritional support since most owners provide a commercial feed to their animals and treat them more than once per day. Thus, we speculate that the prevailing economic situation of respondents (middle class) may have facilitated the purchase of feed. However, the nutritional management is not enough to avoid predation on local fauna. Predation of wildlife by dogs is reported in several circumstances and, hence the presence of dogs in preserved environments can result in reduction of wild species due to competition, predation and disease transmission (MACDONALD \& CARR, 1995; BUTLER \& TOIT, 2002; HEATON et al., 2008). Owners pointed predation of several mammalian species by rural dogs in Viçosa. Dogs are known to attack birds and nests. Hence, the impact on avian fauna is of particular concern for birds that forage and nest in the ground (BANKS \& BRYANT, 2007). Terrestrial and understory bird species are relatively more threatened of extinction in Viçosa region than canopy or medium forest strata bird species (RIBON et al., 2003). The answers of interviewees pointing one-third of the dogs on bird predation activities is conservative for our point of view. In general, birds are cryptic, small and not so easy to observe at night, when around half of dog sample are exploring the forest, pastures and neighbors. In particular, endemic birds are very fragile to environmental disturbance in the Atlantic Forest (RIBON et al., 2003). Thus, additionally to habitat fragmentation, deforestation and poaching (YANES \& SUAREZ, 1996; RIBON et al., 2003), predation by dogs could be a neglected cause of extinction or endangerment of avian species in the Atlantic Forest.

The results for post predatory behavior, suggest that predation is not exclusively for feeding purpose since three out of four dogs do not consume their prey. This is in accordance to what has been described by other authors (MARKS \& DUNCAN, 2009), where domestic dogs were found to cause injury or deaths of its victims but rarely consume them. Similarly, wolves (Canis lupus lupus) present all the behaviors mentioned above, with the difference that the consumption of parts or the entire prey is regular. It is believed that the inhibition of the consumption behavior, such as the intake of prey, may have been selected by humans to ensure ownership and manipulation of hunting by dogs (COPPINGER \& SCHNEIDER, 1995).

It is suggested that dogs have a scavenger diet and a habit of camouflaging its own odor by eating and rolling on rotting carcasses of animals. This behavior has also been reported to be present in other canids (BUTLER \& TOIT, 2002). Therefore, the scavenger behavior by one-third of the dogs, as well as, the likely interactions observed with wild mammals of same habits increase the potential risks of physical contact and disease transmission. Thus, dogs can introduce infectious diseases to the rural property, putting in danger others domestic 
farm animals, increasing the chance of diseases transmission to local wildlife.

Vaccination coverage against rabies is supported by the government and has shown to be efficient, since more than $95 \%$ of dogs were immunized against this disease. The percentage of dogs immunized against CVD plus parvovirus in the rural area of Viçosa is low and near to that reported for Coquimbo's rural area (Chile), where 18\% were vaccinated (ACOSTA-JAMETT et al., 2010). Studies on the incidence of epidemics in wild carnivores have shown that unvaccinated domestic dogs are chained in the epidemiology of canine distemper and parvovirus in various regions of the World (DASZAK et al., 2000; DEEM et al. 2000). Furthermore, even though there are no systematic data on the incidence of canine distemper and parvovirus in wild animals from this region, there is the risk of spread of these diseases.

In conclusion, this study has shown that the main roles played by rural dogs from Viçosa are guarding and companionship. Conversely, some dogs do not have specific duties and appear to be traces of past roles. In addition, despite the adequate diet dogs receive they are not managed to avoid predatory attacks in the local wildlife area. Moreover, our results revealed that the dogs from the region of Viçosa are potential predators and disseminating agents of fatal diseases in wildlife due to the lack of proper confinement in the rural properties allied to inadequate vaccination.

\section{BIOETHICS COMMITTEE \\ AND \\ BIOSSECURITY}

The project was approved by the Human Research Ethical Committee of the Universidade Federal de Viçosa (License number 25/2011).

\section{REFERENCES}

ACOSTA-JAMETT, G. et al. Demography of domestic dogs in rural and urban areas of the Coquimbo region of Chile and implications for disease transmission. Preventive Veterinary Medicine, v. 94, p. 272-281, 2010. Disponível em <http://www.sciencedirect.com/ science/article/pii/S016758771000005X\#>. Acesso em Fev 2011.

ALVES, R.R.N. et al. Hunting strategies used in the semi-arid region of northeastern Brazil. Journal of Ethnobiology and Ethnomedicine, v.5, p.1-16, 2009. Availabrl from: Disponível em: <http://www.ethnobiomed.com/content/5/1/12>. Accessed: Mar. 2011.

BANKS, P.B.; BRYANT, J.V. Four-legged friend or foe? Dog walking displaces native birds from natural areas. Biology Letters, v.3, p.611613, 2007. Available from: <http://rsbl.royalsocietypublishing.org/ content/3/6/611.long>. Accessed: Mar. 2010.
BUTLER, J.R.A.; BINGHAM, J. Demography and dog-human relationships of the dog population in Zimbabwean communal lands. Veterinary Record, v.47, p.442-446, 2000. Available from: <http://veterinaryrecord.bmj.com/content/147/16/442.abstract>. Accessed: Jul. 2010.

BUTLER, J.R.A.; TOIT, J.T. Diet of free ranging dogs (Canis familiaris) in rural Zimbabwe: implications for wild scavengers on the periphery of wildlife reserves. Animal Conservation, v.5, p.29-37, 2002. Available from: <http://onlinelibrary.wiley. com/doi/10.1017/S136794300200104X>. Accessed: Mar. 2010 .

CARNIELI JR., P. et al. Molecular characterization of rabies virus isolates from dogs and crab-eating foxes in Northeastern Brazil. Virus Research, v.141, p.81-89, 2009.

COPPINGER, R.; SCHNEIDER, R. Evolution of working dogs. In: SERPELL, J. The domestic dog: its evolution, behaviour, and interactions with people. Cambridge: Cambridge University, 1995. p.21-47.

DANIELS, T.J.; BEKOFF, M. Population and social biology of freeranging dogs, Canis familiaris. Journal of Mammalogy, v.70, p. 754-762, 1989.

DASZAK, P. et al. Emerging infectious diseases of wildlife threats to biodiversity and human health. Science, v.287, p.443449, 2000. Available from: <http://www.sciencemag.org/ content/287/5452/443>. Accessed: Mar. 2010.

DEEM, S.L. et al. Canine distemper in terrestrial carnivores: a review. Journal of Zoo and Wildlife Medicine, v.31, p.441451, 2000. Available from: <http://www.bioone.org/doi/ full/10.1638/1042-7260\%282000\%29031\%5B0441\%3ACDITCA \%5D2.0.CO\%3B2>. Accessed: Jun. 2011.

FERRANTE, V.L.S. et al. Um modelo de análise sócio-econômica: construção e resultados obtidos. Revista de Saúde Pública, v.10, p.177-190, 1976.

HEATON, J.S. et al. Comparison of effects of humans versus wildlife-detector dogs. Southeastern Naturalist, v.53, p.472-479, 2008. Available from: <http://www.bioone.org/doi/full/10.1894/ PAS-03.1>. Accessed: Jan. 2011.

HOGAN, D.J. Demographic dynamics and environmental change in Brazil. Ambiente \& Sociedade, v.13, p.1-28, 2010.

IBGE (INSTITUTO BRASILEIRO DE GEOGRAFIA E ESTATÍSTICA). Dados do censo demográfico 2010. Available from: <http://www.ibge.gov.br/cidadesat/link.php?codmun=317130>. Accessed: Mar. 2012.

KITALA, P. et al. Dog ecology and demography information to support the planning of rabies control in Machakos District, Kenya. Acta Tropica, v.78, p.217-230, 2001. Available from: <http:// www.biomedcentral.com/1746-6148/5/21>. Accessed: May, 2011.

MACDONALD, D.W.; CARR, G. Variation in dog society: between resource dispersion and social flux. In: SERPELL, J. The domestic dog: its evolution, behaviour, and interactions with people. Cambridge: Cambridge University, 1995. p.199-216.

MARKS, B.K.; DUNCAN, R.S. Use of forest edges by freeranging cats and dogs in an urban forest fragment. Southeastern 
Naturalist, v.8, p.427-436, 2009. Available from: URL: <http://www. bioone.org/doi/full/10.1656/058.008.0305>. Accessed: Nov. 2012.

PEREIRA, R.A. et al. Caracterização da paisagem, com ênfase em fragmentos florestais, do município de Viçosa, Minas Gerais. Revista Árvore, v.25, p.327-333, 2001.

PEREIRA, M.F.V. Contradições de uma "cidade científica”: processo de urbanização e especialização territorial em Viçosa (MG). Caminhos de Geografia, v.18, p.197-206, 2005.

PRADO, M.R. et al. Mamíferos de médio e grande porte em um fragmento de Mata Atlântica, Minas Gerais, Brasil. Revista Árvore, v.32, p.741-749, 2008.

RIBON, R. et al. Bird extinctions in Atlantic Forest fragments of the Viçosa region, southeastern Brazil. Conservation Biology, v.17, p.1827-1839, 2003. Available from: <http://onlinelibrary.wiley.com/ doi/10.1111/j.1523-1739.2003.00377.x/full>. Accessed: Jun. 2012.

STEFFENSMEIER, D.; ALLAN, E. Gender and crime: toward a gendered theory of female offending. Annual Review of Sociology, v.22, p.459-487, 1996. Available from: <http://www. jstor.org/stable/10.2307/2083439>. Accessed: Jan. 2011.

SVARTBERG, K. Breed-typical behaviour in dogs - historical remnants or recent constructs? Applied Animal Behaviour Science, v.96, p.293-313, 2006. Available from: <http://www.sciencedirect. com/science/article/pii/S0168159105001607>. Accessed: Jan. 2011.
VERDADE, L.M.; CAMPOS, C.B. How much is a puma worth? Economic compensation as an alternative for the conflict between wildlife conservation and livestock production in Brazil. Biota Neotropica, v.4, p.1-4, 2004.

WELLS, D.L.; HEPPER, P.G. Male and female dogs respond differently to men and women. Applied Animal Behaviour Science, v.61, p.341-349, 1999. Available from: <http://www. sciencedirect.com/science/article/pii/S0168159198002020>. Accessed: Jan. 2011.

WHITEMAN, C.W. et al. Human and domestic animal populations as a potential threat to wild carnivore conservation in a fragmented landscape from the Eastern Brazilian Amazon. Biological Conservation, v.138, p.290-296, 2007. Available from: <http://www. scielo.br/scielo.php?pid=S1519-69842010000500010\&script=sci_ arttext>. Accessed: Jan. 2012.

WIRANT, S.C.; MCGUIRE, B. Urinary behavior of female domestic dogs (Canis familiaris): influence of reproductive status, location, and age. Applied Animal Behavior Science, v.85, p.335-348, 2004. Available from: <http://www.sciencedirect.com/ science/article/pii/S0168159103002442>. Accessed: Abr. 2012.

YANES M.; SUAREZ, F. Incidental nest predation and lark conservation in an Iberian semiarid shrubsteppe. Conservation Biology, v.10, p.881-887, 1996. Available from: <http://onlinelibrary. wiley.com/doi/10.1046/j.1523-1739.1996.10030881.x/>. Accessed: Mar. 2012. 